Nina Pološki Vokić*

Vinko Mostarac **
JEL klasifikacija: M12, M50, M39, M20

Prethodno priopćenje

https://doi.org/10.32910/ep.72.3.1

\title{
OBILJEŽJA I DIMENZIJE PRIVLAČNOSTI POSLODAVACA ZA EKONOMISTE
}

Rad empirijski istražuje obilježja i dimenzije koje poslodavce čine poželjnijima za najmlađu generaciju visokoobrazovanih ekonomista u Hrvatskoj, s obzirom na manjak istraživanja u ovom području. Također, istraženo je u kojoj je mjeri smisleno segmentirati signale koje poslodavci odašilju na tržište rada kako bi privukli pripadnike najmlađe generacije visokoobrazovanih ekonomista različitih socio-demografskih obilježja. Anketno istraživanje provedeno na uzorku 407 studenata sveučilišnih diplomskih studija korištenjem „Skale privlačnosti poslodavca“ Berthona, Ewinga i Haha (2005) je ukazalo da ispitanici preferiraju „Razvojnu dimenziju“ privlačnosti poslodavca. Dodatno, na temelju inferencijalne statistike zaključeno je da su dimenzije privlačnosti poslodavaca univerzalne, odnosno da u značajnoj mjeri ne ovise o socio-demografskim obilježjima ispitanika. Proizlazi da poslodavci koji žele privući i/ili zadržati u organizaciji visoko-obrazovane ekonomiste mlađih generacija trebaju istima osiguravati prilike za osobni i profesionalni razvoj, bez obzira kojem segmentu prema svojim osobnim obilježjima oni pripadaju.

Ključne riječi: izgradnja marke poslodavca, privlačnost poslodavca, obilježjaldimenzije privlačnosti poslodavca, socio-demografska obilježja pojedinca, ekonomisti, Hrvatska, Skala privlačnosti poslodavca

* N. Pološki Vokić, dr. sc., redovita profesorica u trajnom zvanju, Sveučilište u Zagrebu, Ekonomski fakultet - Zagreb (e-mail: npoloski@efzg.hr)

** V. Mostarac, mag. oec., Hrvatska gospodarska komora (e-mail: mo.s.7@hotmail.com). Rad je primljen u uredništvo 25.07.2019. godine, a prihvaćen je za objavu 23.06.2020. godine. 


\section{UVOD}

Jedan od najvećih stručnjaka za ljudski kapital i njegovo mjerenje, Jac Fitz-enz, još je prije više od dva desetljeća istaknuo da svi priznaju kako su ljudi ključni resurs na novom svjetskom tržištu, a sva ostala imovina nije ništa drugo doli roba koju se može kupiti po tržišnim cijenama, zbog toga što samo ljudski resursi mogu učiti, rasti i doprinositi (Fitz-enz, 1995, str. 45.). Sukladno tome, globalno je rasplamsan rat za talente (engl. war for talents), a jedna od strategija koju koriste organizacije kako bi bile uspješne u toj borbi je izgradnja marke poslodavca (engl. employer branding) odnosno izgradnja marke ,poželjnog poslodavca“ (engl. employer of choice) (Backhaus i Tikoo, 2004; Rampl i Kenning, 2014; Adler i Ghiselli, 2015).

Marka poslodavca (engl. employer brand), kao „paket” funkcionalnih, ekonomskih i psiholoških koristi koji je važan za donošenje odluke od strane pojedinca o zapošljavanju u nekoj organizaciji i identificiranju s njom (Ambler i Barrow, 1996), ukoliko je „dobra“, rezultira mnogim koristima, od kojih su zasigurno ključne uspješno pribavljanje talenata sa superiornim znanjima i vještinama te angažiranje i zadržavanje „,najboljih letača“ (engl. high-flyers) (Pološki Vokić i Mostarac, 2018).

I vanjska (prema potencijalnim zaposlenicima) i unutarnja (prema trenutnim zaposlenicima) marka poslodavca temelje se na poslodavčevoj ponudi vrijednosti (engl. employer value proposition). Iz tog je razloga važno poslodavčevu ponudu vrijednosti uskladiti s potrebama i željama idealnih segmenata sadašnjih i budućih zaposlenika. Jedan od načina kako poslodavci osiguravaju da je njihova ponuda vrijednosti usklađena s preferencijama sadašnjih i mogućih zaposlenika je praćenje čimbenika privlačnosti poslodavca (engl. employer attractiveness factors) te razvijanje i primjena sukladnih praksi upravljanja organizacijom i ljudima. Razumijevanje obilježja i dimenzija privlačnosti poslodavca, koje Arachchige i Robertson (2011) definiraju kao percipirane koristi koje potencijalni/sadašnji zaposlenik poistovjećuje s organizacijom, važno je kako bi aktivnosti izgradnje marke poslodavca neke organizacije bile usklađene s očekivanjima ciljnih segmenata zaposlenika.

Temeljeno na teoriji signaliziranja (engl. signaling theory), koja podrazumijeva sustavno signaliziranje na tržištu rada onih elemenata koji organizaciju čine privlačnim mjestom za rad (vidi Holtbrügge i Kreppel, 2015; Lievens i Slaughter, 2016; Ahamad, 2019), ovaj se rad bavi istraživanjem obilježja i dimenzija koje poslodavce čine poželjnijima za najmlađu generaciju visokoobrazovanih ekonomista u Hrvatskoj. Naime, stručnjaci, kao na primjer Kumari i Saini (2018), ističu kako su istraživanja čimbenika privlačnosti poslodavaca koji zadovoljavaju očekivanja nove generacije tražitelja posla brojčano ograničena, a posebice su ovi čimbenici nedostatno istraživani na području istočne Europe. Nadalje, rad je usmjeren na preferencije budućih magistara ekonomije, kao jednog od „najzapošljivijih” i 
„najzapošljavanijih” kontingenata visoko-obrazovane radne snage. Konačno, kako ističu Sommer, Heidenreich i Handrich (2016), prisutan je nedostatak empirijskih istraživanja koja se ne bave opće poželjnim dimenzijama privlačnosti poslodavaca nego ih segmentiraju, zbog čega su u ovom radu u obzir uzete i neke odrednice različitosti (npr. spol, smjer studija, uspješnost u studiju, radno iskustvo), koje od poslodavaca traže da signale koje odašilju na tržište rada prilagođavaju različitim ciljnim segmentima budućih zaposlenika.

U teorijskom dijelu rada određen je pojam privlačnosti poslodavca te je dan pregled dosadašnjih istraživanja o obilježjima pojedinaca povezanima s poželjnim obilježjima poslodavaca. U empirijskom dijelu rada opisana je metodologija provedenog empirijskog istraživanja te su prikazani rezultati anketnog istraživanja provedenog na uzorku 407 studenata sveučilišnih diplomskih studija Ekonomskog fakulteta u Zagrebu. Rad završava raspravom i zaključcima temeljenima na teorijskim i empirijskim nalazima.

\section{TEORIJSKI OKVIR}

\subsection{Pojam privlačnost poslodavca}

Pojam privlačnog poslodavca odnosi se na koristi koje potencijalni ili postojeći zaposlenik opaža kao koristi od rada za određenu organizaciju (Berthon, Ewing i Hah, 2005), odnosno na jedinstvene aspekte okruženja neke organizacije i njene ponude vezane uz radno mjesto (Backhaus i Tikoo, 2004) koji ju čine privlačnom na vanjskom i unutarnjem tržištu rada.

Privlačnost poslodavca za pojedinca je to veća što su obilježja organizacije bliža onome što je posloprimcu važno (Chhabra i Sharma, 2014). Prednost se daje organizacijama čije se osnovne vrijednosti prema procjeni tražitelja posla podudaraju s njihovim osobnim vrijednostima (Backhaus, Stone i Heiner, 2002; Ahamad, 2019). Drugim riječima, pri traženju posla pojedinci, ovisno o svojim vrijednostima, ciljevima, potrebama, očekivanjima, ali i obilježjima osobnosti, cijene različita obilježja poslodavaca (vidi Cable i Turban, 2001; Backhaus i Tikoo, 2004). Navedeno se temelji na teoriji sukladnosti pojedinca i organizacije (engl. personorganization (P-O) fit theory), prema kojoj je poslodavac to privlačniji što je prisutnije preklapanje između obilježja i vrijednosti pojedinca i organizacije (vidi Lievens i Highhouse, 2003; Holtbrügge i Kreppel, 2015; Sommer, Heidenreich i Handrich, 2016; Klimkiewicz i Oltra, 2017), ali i teoriji društvenog identiteta (engl. social identity theory), prema kojoj se pojedinci identificiraju odnosno sami sebe 
poimaju (engl. self-concept) kroz svoje članstvo u određenim društvenim skupinama (vidi Backhaus, Stone i Heiner, 2002; Rampl i Kenning, 2014).

Iz perspektive pojedinca, privlačnost organizacije/a je povezana s odlukom o prijavi na natječaj za posao, zapošljavanju, horizontalnom i vertikalnom napredovanju te ostanku ili odlasku iz organizacije (vidi Pattnaik i Misra, 2014; Reis, Braga i Trullen, 2017), dakle sa svim karijernim odlukama. Iz perspektive organizacije, percepcija privlačnosti poslodavca temelj je za uspjeh organizacije pri privlačenju i zadržavanju talenata (vidi Berthon, Ewing i Hah, 2005; Pattnaik i Misra, 2014). No, osim pobjede u ratu za talente, dokazane su i mnoge druge koristi od izgradnje marke poželjnog poslodavca (Sivertzen, Nilsen i Olafsen, 2013), kao što su niži troškovi privlačenja novih zaposlenika (Knox i Freeman, 2006), niže stope apsentizma i fluktuacije zaposlenika (Kucherov i Zavyalova, 2012; Adler i Ghiselli, 2015), veće zadovoljstvo i uspjeh na radu zaposlenika (Rampl i Kenning, 2014), veća inovativnost i uspješnije kreiranje znanja (Sommer, Heidenreich i Handrich, 2016), ali i uspješnije poslovanje organizacije (Lievens i Slaughter, 2016).

\subsection{Obilježja i dimenzije privlačnosti poslodavca}

Literatura navodi mnoga obilježja privlačnosti poslodavca. Najčešće korištena podjela je ona na funkcionalna i simbolička obilježja (vidi Lievens i Highhouse, 2003; Backhaus i Tikoo, 2004; Lievens i Slaughter, 2016). Pod funkcionalnim odnosno instrumentalnim obilježjima privlačnosti poslodavca podrazumijevaju se objektivni, opipljivi sadržaji koji imaju utilitarnu vrijednost (kao što su plaća, bonusi i poticaji, pogodnosti, sigurnost posla, uvjeti rada (uključujući sate rada), ravnoteža privatnog i poslovnog života te prilike za učenje, obuku, razvoj karijere, napredovanje i odlazak na međunarodne zadatke), dok su simbolička obilježja subjektivni, emocionalni, apstraktni odnosno neopipljivi sadržaji koji imaju simboličku vrijednost (kao što su organizacijska kultura, radna klima, stil vođenja, ponos zbog rada u organizaciji, ugled i popularnost organizacije te vjerodostojnost, inovativnost i društveno odgovorno poslovanje organizacije) (na temelju Backhaus, Stone i Heiner, 2002; Lievens i Highhouse, 2003; Holtbrügge i Kreppel, 2015; Lievens i Slaughter, 2016; Sommer, Heidenreich i Handrich, 2016; Ahamad, 2019). Neki autori navode i treću skupinu obilježja privlačnosti poslodavaca - iskustvena obilježja, koja se odnose na stvarna iskustva vezana uz nekog poslodavca (vidi Lievens i Slaughter, 2016), u vidu iskustava prilikom prijave za posao, postupka odabira ili rada u organizaciji.

Pojedinačno se kao važna obilježja privlačnosti poslodavca u današnje vrijeme, i to posebice za mlađe generacije zaposlenika, ističu društvena odgovornost or- 
ganizacije (Turban i Greening, 1997; Backhaus, Stone i Heiner, 2002; Klimkiewicz i Oltra, 2017), cijenjenje različitosti (Backhaus, Stone i Heiner, 2002), ravnoteža privatnog i poslovnog života (Kumari i Saini, 2018), radno okruženje u kojem pojedinci mogu biti vjerodostojni tj. djelovati u skladu sa svojim vrijednostima i uvjerenjima (engl. workplace authenticity) (Reis, Braga i Trullen, 2017) te korištenje društvenih medija od strane organizacije (Sivertzen, Nilsen i Olafsen, 2013).

Najpoznatija tipologija dimenzija privlačnosti poslodavca je ona Berthona, Ewinga i Haha iz 2005. godine, a na kojoj se temelji i empirijsko istraživanje prikazano u ovom članku. Ovi autori privlačnost poslodavca određuju kao petodimenzionalni konstrukt kojeg čine sljedeće dimenzije (Berthon, Ewing i Hah, 2005): (1.) interesna vrijednost - uzbudljivo radno okruženje, novi oblici rada, korištenje kreativnosti zaposlenika za proizvodnju visoko-kvalitetnih, inovativnih proizvoda i usluga, (2.) društvena vrijednost - radno okruženje koje je zabavno, sretno, osigurava dobre odnose među kolegama i timsku atmosferu, (3.) ekonomska vrijednost - iznad-prosječna plaća i privlačan cjelokupni kompenzacijski paket, sigurnost posla i prilike za napredovanje, (4.) razvojna vrijednost - priznavanje uspjeha, okruženje koje omogućuje samo-realizaciju i izgradnju samopouzdanja pojedinca te prilike za prikupljanje iskustava potrebnih za daljnji razvoj karijere koja su dobra odskočna daska za buduće zaposlenje i (5.) primijenjena vrijednost - korištenje onoga što je pojedinac prethodno naučio i podučavanje drugih, u okruženju koje je usmjereno na klijente i društveno odgovorno. Ova je tipologija usavršena i proširena verzija trodimenzionalne strukture koja obuhvaća psihološke, funkcionalne i ekonomske koristi koju su predložili Ambler i Barrow 1996. godine - prethodno navedene dimenzije 1. i 2. odnose se na psihološke, dimenzije 4. i 5. na funkcionalne, a dimenzija 3. na ekonomske koristi.

Obilježja privlačnosti poslodavca mogu se grupirati i s obzirom na to jesu li vezana uz posao (engl. job attributes) ili organizaciju (engl. organization attributes) (Pattnaik i Misra, 2014), a mnogi autori ističu i ulogu ,demografskih“ obilježja organizacija kao što su veličina, lokacija i matična zemlja organizacije te industrija u kojoj organizacija djeluje (vidi Lievens i Highhouse, 2003; Berthon, Ewing i Hah, 2005; Knox i Freeman, 2006; Holtbrügge i Kreppel, 2015; Sommer, Heidenreich i Handrich, 2016).

\subsection{Obiljě̌ja pojedinaca povezana s čimbenicima privlačnosti poslodavca}

Dosadašnja istraživanja pokazuju da je važnost koju pojedinim obilježjima privlačnosti poslodavaca dodjeljuju ispitanici povezana s njihovim obilježjima. Iako nalazi nisu jedinstveni, obilježja pojedinaca koja su se pokazala značajni- 
ma u većini istraživanja su spol, dob, nacionalnost, razina obrazovanja, uspjeh na studiju, status ispitanika (student vs. zaposlenik), radno iskustvo, hijerarhijska razina, ali i obilježja osobnosti (vidi npr. Backhaus, Stone i Heiner, 2002; Terjesen, Vinnicombe i Freeman, 2007; Arachchige i Robertson, 2011; Alniacik i Alniacik, 2012; Holtbrügge i Kreppel, 2015; Sommer, Heidenreich i Handrich, 2016; Reis, Braga i Trullen, 2017).

Tako se, na primjer, pokazalo da je muškarcima važnija visoka početna plaća (Terjesen, Vinnicombe i Freeman, 2007), da je ženama važnija društvena odgovornost organizacije (Backhaus, Stone i Heiner, 2002), da su mlađim osobama važnije prilike za razvoj karijere i ravnoteža privatnog i poslovnog života (Kumari i Saini, 2018), da je starijim zaposlenicima važnije da mogu biti vjerodostojni na radnom mjestu (Reis, Braga i Trullen, 2017), da je pripadnicima manjinskih skupina važnije cijenjene različitosti (Backhaus, Stone i Heiner, 2002) te da je inovativnim pojedincima važnije da je u organizaciji prisutna organizacijska kultura inovativnosti (Sommer, Heidenreich i Handrich, 2016).

\section{METODOLOGIJA}

\subsection{Instrument istraživanja}

Preferirana obilježja i dimenzije privlačnosti poslodavca istražene su korištenjem Skale privlačnosti poslodavca (engl. Employer attractiveness scale - EmpAt scale), najčešće korištenog instrumenta u znanstvenim istraživanjima (vidi npr. Roy, 2008; Arachchige i Robertson, 2011; Alniacik i Alniacik, 2012; Sivertzen, Nilsen i Olafsen, 2013; Gozukara i Hatipoglu, 2016; Reis, Braga i Trullen, 2017), kojeg su razvili Berthon, Ewing i Hah 2005. godine. Skalu čini 25 čestica putem kojih se mjeri poželjnost pet prethodno opisanih dimenzija privlačnosti poslodavca na način da ispitanici na skali Likertovog tipa od 1 (uopće nije važno) do 5 (izrazito važno) ocjenjuju važnost elemenata pri odabiru potencijalnog poslodavca. Skala je razvijena upravo za istraživanje obilježja i dimenzija privlačnosti poslodavaca za studente završnih godina studija (Berthon, Ewing i Hah, 2005), a koji su ispitanici i u ovom istraživanju.

Drugi dio upitnika obuhvaćao je devet pitanja vezanih uz obilježja ispitanika koja omogućuju njihovu segmentaciju, a koja su potencijalno povezana s njihovim preferencijama obilježja i dimenzija privlačnosti poslodavca - spol, smjer diplomskog studija, prosjek ocjena na preddiplomskom studiju, prisutnost i broj godina radnog iskustva, prisutnost i broj godina relevantnog radnog iskustva (radno 
iskustvo u području studiranja), razina prosječnih mjesečnih primanja ispitanika i dostatnost ukupnih mjesečnih primanja kućanstva ispitanika.

\subsection{Uzorak i proces prikupljanja podataka}

U istraživanju je sudjelovalo 407 ispitanika, što čini 52,65 \% ukupne populacije studenata upisanih na sveučilišne diplomske studije na Ekonomskom fakultetu u Zagrebu (EFZG) u akademskoj godini 2017./2018. Socio-demografski profil studenata u uzorku prikazan je u Tablici 1.

\section{Tablica 1.}

\section{PROFIL STUDENATA U UZORKU}

\begin{tabular}{|c|c|}
\hline $\begin{array}{l}\text { Socio-demografsko } \\
\text { obilježje ispitanika }\end{array}$ & Relativne frekvencije / aritmetičke sredine (M) \\
\hline spol & $\mathrm{M}-25,2 \% ; \check{Z}-74,8 \%$ \\
\hline smjer diplomskog studija & $\begin{array}{l}\text { Analiza i poslovno planiranje (AiPP) - 7,4 \%; Financije } \\
\text { (Fin) - 15,5 \%; Marketing (Mar) - 8,9 \%; Menadžerska } \\
\text { informatika (MInf) - 7,1 \%; Menadžment (Men) - 26,9 \%; } \\
\text { Računovodstvo i revizija (RiR) - 25,4\%; Trgovina (Trg) - } \\
\text { 4,4 \%; Turizam (Tur) - 4,4 \% }\end{array}$ \\
\hline $\begin{array}{l}\text { prosjek ocjena na } \\
\text { preddiplomskom studiju }\end{array}$ & $\mathrm{M}=3,69(\min =2,4 ; \max =5,00)$ \\
\hline $\begin{array}{l}\text { prisutnost radnog } \\
\text { iskustva }\end{array}$ & $\mathrm{DA}-83 \% ; \mathrm{NE}-17 \%$ \\
\hline $\begin{array}{l}\text { broj godina radnog } \\
\text { iskustva }\end{array}$ & $\mathrm{M}=2,86(\min =0,5 ; \max =15,00)$ \\
\hline $\begin{array}{l}\text { prisutnost relevantnog } \\
\text { radnog iskustva }\end{array}$ & $\mathrm{DA}-54,9 \% ; \mathrm{NE}-45,1 \%$ \\
\hline $\begin{array}{l}\text { broj godina relevantnog } \\
\text { radnog iskustva }\end{array}$ & $\mathrm{M}=1,73(\min =0,5 ; \max =8,00)$ \\
\hline $\begin{array}{l}\text { razina prosječnih } \\
\text { mjesečnih primanja } \\
\text { ispitanika }\end{array}$ & $\begin{array}{l}\text { bez mjesečnih primanja }-27,8 \% ;<2.000 \mathrm{kn}-15 \% ; 2.000 \\
\text { do } 4.000 \mathrm{kn}-43,5 \% ; 4.000 \text { do } 6.000-9,5 \% ;>6.000 \mathrm{kn}- \\
4,2 \%\end{array}$ \\
\hline $\begin{array}{l}\text { dostatnost ukupnih } \\
\text { mjesečnih primanja } \\
\text { kućanstva ispitanika }\end{array}$ & $\begin{array}{l}\text { uopće nisu dostatna }-3,7 \% \text {; nisu dostatna }-16,6 \% \text {; dostatna } \\
\text { su - 66,3\%; više su nego dostatna }-13,4 \%\end{array}$ \\
\hline
\end{tabular}


Ispitanici su popunjavali otisnute upitnike za vrijeme nastave iz obaveznih predmeta. Istraživanje je provedeno u zimskom semestru akademske godine 2017./2018., a popunjavanje upitnika je trajalo 10-tak minuta.

\subsection{Obrada podataka}

Osim deskriptivne statistike, za analizu povezanosti između obilježja ispitanika i njihovih preferencija obilježja i dimenzija privlačnosti poslodavaca korištene su metode inferencijalne statistike (Mann-Whitney U testiranje, KruskallWallis H testiranje i izračun Pearsonovog koeficijenta korelacije) sukladno vrsti varijabli. Također, izračunat je Cronbach alfa koeficijent pouzdanosti korištene skale privlačnosti poslodavca. Dobiveni koeficijent od 0,86 zadovoljava kriterij od 0,8 (vidi Bryman i Cramer, 2011) i ukazuje na unutarnju pouzdanost instrumenta (koeficijent originalne skale iznosi 0,96 (Berthon, Ewing i Hah, 2005)).

\section{REZULTATI}

Tablica 2. pokazuje da su za studente diplomskih studija EFZG-a sve dimenzije privlačnosti poslodavca važne (aritmetičke sredine od 3,89 do 4,29), a jedna čak izrazito važna (aritmetička sredina blizu 4,5). Najpoželjnija dimenzija privlačnosti poslodavca je „Razvojna vrijednost“ $(M=4,42)$, dok je najmanje poželjna dimenzija „Primijenjena vrijednost“ $(M=3,89)$. Tablica također navodi najpoželjnije i najmanje poželjno pojedinačno obilježje poslodavaca za svaku od dimenzija, gdje vidimo da je ispitanicima najvažnije pojedinačno obilježje ,stjecanje iskustva za nastavak osobne karijere“ ( $M=4,66)$, a najmanje poželjno pojedinačno obilježje „organizacija orijentirana prema potrošaču“ $(M=3,65)$. 
Tablica 2 .

\section{PROSJEČNE VRIJEDNOSTI, RANG, NAJPOŽELJNIJE I NAJMANJE POŽELJNO OBILJEŽJE PRIVLAČNOSTI POSLODAVCA ZA PET DIMENZIJA PRIVLAČNOSTI POSLODAVACA}

\begin{tabular}{|c|c|c|c|c|c|c|}
\hline \multirow{2}{*}{$\begin{array}{l}\text { Dimenzije } \\
\text { privlačnosti } \\
\text { poslodavca }\end{array}$} & \multirow[t]{2}{*}{ M } & \multirow[t]{2}{*}{ Rang } & \multicolumn{2}{|c|}{$\begin{array}{c}\text { Najpoželjnija obilježja } \\
\text { poslodavca }\end{array}$} & \multicolumn{2}{|c|}{$\begin{array}{c}\text { Najmanje poželjna } \\
\text { obilježja poslodavca }\end{array}$} \\
\hline & & & Obilježje & $\mathrm{M}$ & Obilježje & $\mathrm{M}$ \\
\hline $\begin{array}{l}\text { Razvojna } \\
\text { vrijednost }\end{array}$ & 4,42 & 1 & $\begin{array}{c}\text { stjecanje iskustva } \\
\text { za nastavak osobne } \\
\text { karijere }\end{array}$ & 4,66 & $\begin{array}{l}\text { priznanje od strane } \\
\text { menadžmenta }\end{array}$ & 3,87 \\
\hline $\begin{array}{l}\text { Društvena } \\
\text { vrijednost }\end{array}$ & 4,29 & 2 & $\begin{array}{l}\text { dobar odnos s } \\
\text { kolegama }\end{array}$ & 4,52 & $\begin{array}{c}\text { potpora i } \\
\text { ohrabrivanje od } \\
\text { strane kolega }\end{array}$ & 4,04 \\
\hline $\begin{array}{l}\text { Ekonomska } \\
\text { vrijednost }\end{array}$ & 4,26 & 3 & $\begin{array}{c}\text { dobra prilika za } \\
\text { napredovanje } \\
\text { unutar organizacije }\end{array}$ & 4,55 & $\begin{array}{l}\text { mogućnost } \\
\text { stjecanja } \\
\text { međuodjelnog } \\
\text { iskustva } \\
\end{array}$ & 3,88 \\
\hline $\begin{array}{l}\text { Interesna } \\
\text { vrijednost }\end{array}$ & 3,95 & 4 & $\begin{array}{l}\text { organizacija cijeni } \\
\text { i koristi kreativnost } \\
\text { svojih zaposlenika }\end{array}$ & 4,24 & $\begin{array}{c}\text { organizacija } \\
\text { proizvodi } \\
\text { inovativne } \\
\text { proizvode i usluge }\end{array}$ & 3,68 \\
\hline $\begin{array}{l}\text { Primijenjena } \\
\text { vrijednost }\end{array}$ & 3,89 & 5 & $\begin{array}{c}\text { osjećaj } \\
\text { prihvaćenosti i } \\
\text { pripadanja }\end{array}$ & 4,31 & $\begin{array}{c}\text { organizacija } \\
\text { orijentirana prema } \\
\text { potrošaču }\end{array}$ & 3,65 \\
\hline
\end{tabular}

Dodatno je zanimljivo istaknuti da su od pet najviše rangiranih pojedinačnih obilježja privlačnosti poslodavaca čak tri obilježja koja čine dimenziju „Razvojna vrijednost“ (,stjecanje iskustva za nastavak osobne karijere“ (M = 4,66), ,osjećaj osobnog zadovoljstva zbog rada u organizaciji“ $(M=4,61)$ i ,osjećaj samopouzdanja kao rezultat rada u organizaciji“ $(M=4,51))$. Treće rangirano obilježje - „dobra prilika za napredovanje unutar organizacije“, čini dimenziju „Ekonomska vrijednost“ ( $M=4,55)$, a peto - ,dobar odnos s kolegama“, dimenziju „Društvena vrijednost“" $(M=4,52)$. Među pet najlošije rangiranih pojedinačnih obilježja privlačnosti poslodavaca čak su tri obilježja koja čine dimenziju „Primijenjena vrijednost“ (,organizacija orijentirana prema potrošaču“ $(M=3,65)$, „mogućnost podučavanja drugih temeljem stečenih znanja i vještina“ ( $\mathrm{M}=3,73)$ i „društveno odgovorna organizacija - „vraća“ društvu“ $(\mathrm{M}=3,85))$ te dva obilježja koja čine dimenziju „Interesna vrijednost“ (,organizacija proizvodi inovativne proizvode i usluge“ (M $=3,68)$ i ,organizacija proizvodi visoko kvalitetne proizvode i usluge“ $(M=3,76))$. 
Tablica 3. prikazuje obilježja ispitanika koja su se pokazala statistički značajno povezanima s dimenzijama privlačnosti poslodavca - „spol“, „,smjer studija“ i „razina prosječnih mjesečnih primanja ispitanika“. Ove su se tri varijable pokazale značajnima za ocjene važnosti tri od pet dimenzija privlačnosti poslodavca, od čega je varijabla „spol“ povezana s jednom, a varijable „smjer studija“ i „razina prosječnih mjesečnih primanja ispitanika" s po dvije dimenzije privlačnosti poslodavca. Nadalje, na temelju tablice proizlazi da se čak šest od devet obilježja ispitanika nije pokazalo statistički značajnima za postojanje razlika u odgovorima ispitanika, i to: ,prosjek ocjena na preddiplomskom studiju“, ,postojanje radnog iskustva ispitanika“, ,,broj godina radnog iskustva“, ,,postojanje relevantnog radnog iskustva ispitanika“, „, broj godina relevantnog radnog iskustva“ i „dostatnost ukupnih mjesečnih primanja kućanstva“.

Tablica 3 .

\section{OBILJEŽJA ISPITANIKA KOJA SU SE POKAZALA STATISTIČKI ZNAČAJNIMA ZA POSTOJANJE RAZLIKA U NJIHOVIM PREFERENCIJAMA DIMENZIJA PRIVLAČNOSTI POSLODAVACA}

\begin{tabular}{|c|c|}
\hline $\begin{array}{l}\text { Dimenzije } \\
\text { privlačnosti } \\
\text { poslodavca }\end{array}$ & Statistički značajna obilježja ispitanika \\
\hline Društvena vrijednost & $\begin{array}{c}\text { Niti jedno obilježje ispitanika se nije pokazalo značajnim za razlike u } \\
\text { preferencijama između skupina. }\end{array}$ \\
\hline Ekonomska vrijednost & 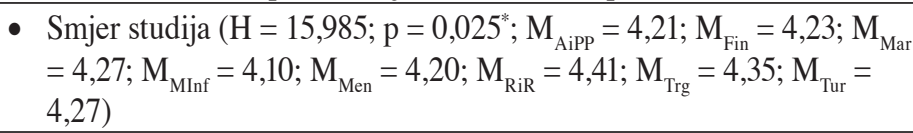 \\
\hline Interesna vrijednost & $\begin{array}{l}\text { - Razina prosječnih mjesečnih primanja ispitanika }(\mathrm{H}=16,484 ; \mathrm{p}= \\
0,002^{* *} ; \mathrm{M}_{\text {BezPrim }}=3,82 ; \mathrm{M}_{<2000}=4,12 ; \mathrm{M}_{2000-4000}=3,98 ; \mathrm{M}_{4000-6000}= \\
\left.3,87 ; \mathrm{M}_{26000}=4,13\right)\end{array}$ \\
\hline $\begin{array}{l}\text { Primijenjena } \\
\text { vrijednost }\end{array}$ & 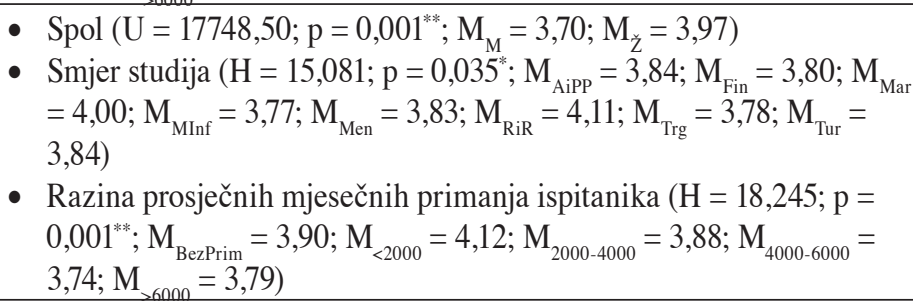 \\
\hline Razvojna vrijednost & $\begin{array}{c}\text { Niti jedno obilježje ispitanika se nije pokazalo značajnim za razlike u } \\
\text { preferencijama između skupina. }\end{array}$ \\
\hline
\end{tabular}

Napomena: ${ }^{*} \mathrm{p}<0.05 ;{ }^{* *} \mathrm{p}<0.01$ 
Inferencijalna statistika je ukazala da je važnost dimenzije „Ekonomska vrijednost" ocijenjena statistički značajno različito s obzirom na smjer studija ispitanika - studenti smjera Računovodstvo i revizija ocijenili su elemente ove dimenzije u prosjeku najvišim, a studenti smjera Menadžerska informatika najnižim ocjenama. Dimenzija privlačnosti poslodavca „Interesna vrijednost““ je statistički značajno različito ocijenjena s obzirom na razinu prosječnih mjesečnih primanja ispitanika - ocijenjena je važnijom od strane ispitanika s primanjima manjim od $2.000 \mathrm{kn}$ i onima s primanjima većim od $6.000 \mathrm{kn}$. Dimenzija „Primijenjena vrijednost“ ocijenjena je statistički značajno različito s obzirom na čak tri obilježja ispitanika - spol, smjer studija i razina prosječnih mjesečnih primanja ispitanika. Ova se dimenzija pokazala statistički značajno važnijom za osobe u uzorku ženskog spola, sa smjera „Računovodstvo i revizija“ te s prihodima manjima od $2.000 \mathrm{kn}$.

\section{RASPRAVA I ZAKLJUČCI}

\subsection{Teorijske implikacije i preporuke za buduća znanstvena istraživanja}

Tri su ključne teorijske implikacije nalaza provedenog empirijskog istraživanja. Kao prvo, istraživanje ukazuje da su obilježja koja poslodavce čine privlačnima za studente u Hrvatskoj (zemlji Istočne Europe) sličnija obilježjima koja preferiraju ispitanici u manje razvijenim zemljama svijeta nego onima na koja ukazuju nalazi novijih istraživanja provedenih u najrazvijenijim zemljama svijeta. Naime, nalazi istraživanja provedenih u zapadnoj Europi ukazuju na privlačnost ,pragmatičnih“ obilježja poslodavaca, kao što su sigurnost posla, visina plaće i izdašnost pogodnosti, odnosno pokazuju da su za privlačnost poslodavaca posebice važna ekonomska obilježja/dimenzije. Na primjer, prema istraživanju Sivertzen, Nilsen i Olafsen (2013) provedenom na uzorku studenata u Norveškoj, od tri najviše rangirana obilježja privlačnosti poslodavca čak su dva ekonomska - ukupan kompenzacijski paket i iznad-prosječna plaća (najveća prosječna ocjena dodijeljena je obilježju „organizacija proizvodi visoko-kvalitetne proizvode i usluge“). Nadalje, u istraživanju Holtbrüggea i Kreppel (2015) provedenom na uzorku zaposlenika u Njemačkoj, čak četiri najviše rangirana obilježja privlačnosti poslodavca odnose na ekonomsku vrijednost - kompenzacije, sigurnost posla, ravnoteža privatnog i poslovnog života te dodatne pogodnosti i usluge. Za razliku od navedenog, ispitanici ovog istraživanja najprivlačnijima smatraju razvojne mogućnosti, dakle poslodavce koji im pružaju prilike za osobni i karijerni razvoj, odnosno one poslodavce koji izgrađuju zadovoljne i samopouzdane zaposlenike s iskustvom i znanjem te koji su dobra odskočna daska za daljnji razvoj karijere. Do istovjetnog su pak na- 
laza došli Reis, Braga i Trullen (2017) za zaposlenike u Brazilu, koji su ustanovili da je „razvojna vrijednost“ ključna dimenzija privlačnosti poslodavca, ali i Pringle i Sharma (2013) koji su ustanovili da su „učenje i razvoj“ te „priznavanje uspjeha" ključne dimenzije privlačnosti poslodavca za studente menadžmenta u Indiji. Slični su nalazi i istraživanja provedenog od strane Arachchige i Robertsona (2013) na Šri Lanki - za studente diplomskog studija od šest najprivlačnijih obilježja poslodavaca četiri su razvojna (prikupljanje iskustva važnih za karijeru, prilike u budućnosti, poticanje samopoštovanja i izgradnja samopouzdanja kod pojedinca), a za studente na poslijediplomskoj razini čak je pet od šest ključnih obilježja privlačnosti poslodavaca vezano uz razvoj (ista četiri te uvažavanje od strane menadžmenta). Kako bi se zamijećene razlike u preferencijama obilježja/dimenzija privlačnosti poslodavaca ispitanika u razvijenim i manje razvijenim zemljama protumačile, potrebno bi bilo provesti komparativno istraživanje (istraživanje koje se uz korištenje iste metodologije provodi istovremeno u više zemalja svijeta), ali i kvalitativna dubinska izviđanja koja bi razlike pripisala konkretnim čimbenicima. Naravno, kako bi se mogli donositi zaključci o obilježjima/dimenzijama privlačnosti poslodavaca u Istočnoj Europi, potrebno bi bilo istovjetna istraživanja provesti i u drugim zemljama u ovoj regiji.

Druga implikacija provedenog istraživanja na teorijskoj razini je naznaka univerzalnosti obilježja odnosno dimenzija privlačnosti poslodavaca za buduće visokoobrazovane zaposlenike ekonomskog usmjerenja. Naime, analiza razlika između odgovora ispitanika različitih socio-demografskih skupina ukazala je da čak šest od devet analiziranih obilježja ispitanika nije statistički značajno za njihove preferencije dimenzija privlačnosti poslodavaca (prosjek ocjena na preddiplomskom studiju, postojanje radnog iskustva ispitanika, broj godina radnog iskustva, postojanje relevantnog radnog iskustva ispitanika, broj godina relevantnog radnog iskustva i dostatnost ukupnih mjesečnih primanja kućanstva), dok su se preostala tri obilježja (spol, smjer studija i razina prosječnih mjesečnih primanja ispitanika) pokazala statistički značajnima za preferencije samo jedne odnosno dvije dimenzije privlačnosti poslodavca. Preciznije, studentice su statistički značajno važnijom ocijenile dimenziju privlačnosti poslodavca „Primijenjena vrijednost“", smjer studija se pokazao statistički značajnom varijablom za ocjenu dimenzija „Ekonomska vrijednost“ i „Primijenjena vrijednost“, a razina prosječnih mjesečnih primanja ispitanika za ocjenu dimenzija „Interesna vrijednost“ i „Primijenjena vrijednost“. No, iako se pokazalo da su neka socio-demografska obilježja ispitanika povezana s varijacijama u njihovim preferencijama, ipak je u većoj mjeri prisutna usuglašenost stavova studenata ekonomskog usmjerenja vezano uz preferirane dimenzije privlačnosti poslodavaca. Štoviše, pronađene razlike nisu sukladne nalazima dosadašnjih istraživanja. Tako se, na primjer, u istraživanju Reisa, Brage i Trullena (2017) spol pokazao statistički značajnom varijablom za preferencije „Razvojne vrijednosti“ i „Društvene vrijednosti“, ali ne i „Primijenjene vrijednosti“ kao što 
je pokazalo provedeno istraživanje. Djelomično je i nepotvrđivanje prethodnih nalaza argument za donošenje zaključka kako su preferencije obilježja/dimenzija privlačnosti poslodavaca za pripadnike različitih socio-demografskih segmenata najmlađe generacije visokoobrazovanih ekonomista zajedničke. Ipak, zaključak o univerzalnosti obilježja/dimenzija privlačnosti poslodavaca za ovu generaciju ekonomista potrebno je dodatno provjeriti istraživanjem stavova studenata ekonomije i na drugim sveučilištima i veleučilištima u Hrvatskoj.

Treća implikacija provedenog empirijskog istraživanja za teoretičare u području izgradnje marke poželjnog poslodavca je vezana uz dva socio-demografska obilježja ispitanika koja su se pokazala relevantnima - smjer studija i razina prosječnih mjesečnih primanja ispitanika. Ove dvije varijable nisu do sada korištene za segmentiranje preferencija obilježja/dimenzija privlačnosti poslodavaca, no statistički značajne razlike u odgovorima ispitanika s obzirom na ova dva obilježja ukazuju da se radi o varijablama čiji je značaj smisleno dalje istraživati. Dodatno, kako bi se u potpunosti istražilo područje segmentacije preferencija obilježja/ dimenzija privlačnosti poslodavaca, buduća istraživanja je potrebno proširiti još nekim varijablama obilježja ispitanika, ali i poslodavaca, kao što su na primjer obilježja osobnosti pojedinaca i industrija djelovanja poslodavaca.

\subsection{Implikacije za organizacije}

Kako ističu Sivertzen, Nilsen i Olafsen (2013), kada poslodavci provode kampanje izgradnje marke poslodavca trebaju znati koji čimbenici zaista osiguravaju da potencijalni i sadašnji zaposlenici steknu odnosno zadrže dobar dojam o organizaciji. Teorijski i empirijski dio ovog rada ukazuju organizacijama, menadžerima, a posebice stručnjacima za ljudske potencijale, koja obilježja/dimenzije čine poslodavce privlačnima najmlađoj generaciji visokoobrazovanih ekonomista. Konkretno, poslodavci pri osmišljavanju, provođenju i komuniciranju poslodavčeve ponude vrijednosti sadašnjim i budućim zaposlenicima ekonomskog usmjerenja, a radi se o profilu zaposlenika koji traže organizacije svih industrija i veličina, naglasak trebaju stavljati na „Razvojnu vrijednost“. Ispitanici najprivlačnijom dimenzijom poslodavca smatraju dimenziju koja se odnosi na prilike za osobni i profesionalni razvoj kroz rad u organizaciji, odnosno elemente kao što su podrška od strane nadređenih, radno okruženje koje se pozitivno odražava na osobno zadovoljstvo i samopouzdanje pojedinca, prilike za stjecanje iskustava važnih za razvoj karijere i općenito posao koji je dobra odskočna daska za buduće zaposlenje.

Dodatno je zanimljivo istaknuti da inferencijalna analiza prikupljenih po-

dataka nije ukazala na statistički značajne razlike u preferencijama „Razvojne 
vrijednost“ od strane ispitanika. Ispitanici ovu dimenziju smatraju najprivlačnijom dimenzijom bez obzira kojem segmentu prema svojim osobnim obilježjima pripadaju. Bez obzira kojeg su spola, smjera studija, koliko su uspješni u studiju mjereno prosjekom ocjena, koliko imaju (relevantnog) radnog iskustva, koliki su im mjesečni prihodi te procjenjuju li mjesečne prihode njihovih kućanstava dostatnima, žele da im njihovi budući poslodavci osiguraju prilike za emocionalni, intelektualni i stručni napredak.

\subsection{Ograničenja istraživanja}

Svako empirijsko istraživanje, a tako i ovo, ima svoja ograničenja. Kao prvo, osim činjenice da je provedeno na uzorku studenata Ekonomskog fakulteta u Zagrebu, odnosno da ne uključuje i studente završnih godina drugih sveučilišta i veleučilišta ekonomskog usmjerenja u Hrvatskoj, istraživanje ograničava i činjenica da su ispitivani stavovi samo najmlađe generacije visokoobrazovanih ekonomista, ali ne i njihovih starijih zaposlenih ali i nezaposlenih kolega. Naime, stavovi studenata se temelje prvenstveno na onome što su čuli na nastavi, a ne toliko na njihovoj upoznatosti sa stvarnim poslovnim okruženjima (Ahamad, 2019), zbog čega se stavovi studenata nerijetko u velikoj mjeri razlikuju od stavova kontingenta zaposlenih koji je značajno veći. Nadalje, kako bi se rezultati mogli poopćiti na sve visokoobrazovane buduće i sadašnje zaposlenike, potrebno je ispitati i stavove visokoobrazovanih stručnjaka drugih profila.

Drugo značajnije ograničenje provedenog empirijskog istraživanja je njegov kros-sekcijski nacrt. Kako ističu mnogi teoretičari (vidi npr. Arachchige i Robertson, 2011; Holtbrügge i Kreppel, 2015; Reis i Braga, 2016), potrebno je provoditi i longitudinalna istraživanja koja prate mijenjaju li se preferencije ispitanika protekom vremena.

\section{IZVORI}

1. Adler, H. i Ghiselli, R. (2015). The Importance of Compensation and Benefits on University Students' Perceptions of Organizations as Potential Employers. Journal of Management and Strategy, 6(1), 1-9. doi: 10.5430/jms.v6n1p1

2. Ahamad, F. (2019). Impact of word-of-mouth, job attributes and relationship strength on employer attractiveness. Management Research Review, online, doi: 10.1108/MRR-11-2017-0382 
3. Alniacik, E. i Alniacik, U. (2012). Identifying dimensions of attractiveness in employer branding: effects of age, gender, and current employment status. Procedia - Social and Behavioral Sciences, (58), 1336-1343. doi: 10.1016/j. sbspro.2012.09.1117

4. Ambler, T. i Barrow, S. (1996). The Employer Brand. Journal of Brand Management, 4(3), 185-206. doi: 10.1057/bm.1996.42

5. Arachchige, B. J. H. i Robertson, A. (2011). Business Student Perceptions of a Preferred Employer: A Study Identifying Determinants of Employer Branding. The IUP Journal of Brand Management, 8(3), 25-46.

6. Backhaus, K. B., Stone, B. A. i Heiner, K. (2002). Exploring the Relationship Between Corporate Social Performance and Employer Attractiveness. Business and Society, 41(3), 292-318. doi: 10.1177/000765030204100300

7. Backhaus, K. i Tikoo, S. (2004). Conceptualizing and researching employer branding. Career Development International, 9(5), 501-517. doi: 10.1108/13620430410550754

8. Berthon, P., Ewing, M. i Hah, L. L. (2005). Captivating company: dimensions of attractiveness in employer branding. International Journal of Advertising, 24(2), 151-172. doi: 10.1080/02650487.2005.11072912

9. Bryman, A. i Cramer, D. (2011). Quantitative Data Analysis with IBM SPSS 17, 18 and 19. London: Routledge.

10. Cable, D. M. i Turban, D. B. (2001). Establishing the Dimensions, Sources and Value of Job Seekers' Employer Knowledge During Recruitment. U G. R. Ferris (Ur.), Research in Personnel and Human Resources Management (str. 115-163). Bingley: Emerald Group Publishing Limited

11. Chhabra, N. L. i Sharma, S. (2014). Employer branding: strategy for improving employer attractiveness. International Journal of Organizational Analysis, 22(1), 48-60. doi: 10.1108/IJOA-09-2011-0513

12. Fitz-enz, J. (1995). How to Measure Human Resources Management. New York, NY: McGraw-Hill, Inc.

13. Gozukara, I. i Hatipoglu, Z. (2016). The Effect of Employer Branding on Employees' Organizational Citizenship Behaviors. International Journal of Business Management and Economic Research, 7(1), 477-485.

14. Holtbrügge, D. i Kreppel, H. (2015). Employer Attractiveness of Chinese, Indian and Russian Firms in Germany: Signaling Effects of HR Practices. Corporate Reputation Review, 18(3), 223-242. doi: 10.1057/crr.2015.12

15. Klimkiewicz, K. i Oltra, V. (2017). Does CSR Enhance Employer Attractiveness? The Role of Millennial Job Seekers' Attitudes. Corporate 
Social Responsibility and Environmental Management, 24(5), 449-463. doi: 10.1002/csr.1419

16. Knox, S. i Freeman, C. (2006). Measuring and Managing Employer Brand Image in the Service Industry. Journal of Marketing Management, 22(7-8), 695-716. doi: 10.1362/026725706778612103

17. Kucherov, D. i Zavyalova, E. (2012). HRD practices and talent management in the companies with the employer brand. European Journal of Training and Development, 36(1), 86-104. doi: 10.1108/03090591211192647

18. Kumari, S. i Saini, G. K. (2018). Do instrumental and symbolic factors interact in influencing employer attractiveness and job pursuit intention? Career Development International, 23(4), 444-462. doi: 10.1108/CDI-03-2018-0069

19. Lievens, F. i Highhouse, S. (2003). The relation of instrumental and symbolic attributes to a company's attractiveness as an employer. Personnel psychology, 56(1), 75-102. doi: 10.1111/j.1744-6570.2003.tb00144.x

20. Lievens, F. i Slaughter, J. E. (2016). Employer Image and Employer Branding: What We Know and What We Need to Know. Annual Review of Organizational Psychology and Organizational Behavior, 3, 407-440. doi: 10.1146/annurevorgpsych-041015-06250

21. Pattnaik, S. K. i Misra, R. K. (2014). Employer Attractiveness: A Conceptual Framework \& Scale Development. Indian Journal of Industrial Relations, 50(2), 318-327.

22. Pingle, S. S. i Sharma, A. (2013). External Employer Attractiveness: A Study of Management Students in India. The Journal Contemporary Management Research, 7(1), 78-95.

23. Pološki Vokić, N. i Mostarac, V. (2018). Is there a need for a change in employer branding practices? - A shift in employer attractiveness attributes/dimensions during the last decade. Proceedings of the $9^{\text {th }}$ International Conference "An Enterprise Odyssey: Managing Change to Achieve Quality Development" (451-463). Zagreb: Ekonomski fakultet - Zagreb.

24. Rampl, L. V. i Kenning, P. (2014). Employer brand trust and affect: linking brand personality to employer brand attractiveness. European Journal of Marketing, 48(1/2), 218-236. doi: 10.1108/EJM-02-2012-0113

25. Reis, G. G. i Braga, B. M. (2016). Employer attractiveness from a generational perspective: Implications for employer branding. Revista de Administracao, 51(1), 103-116. doi: 10.5700/rausp1226

26. Reis, G. G., Braga, B. M. i Trullen, J. (2017). Workplace authenticity as an attribute of employer attractiveness. Personnel Review, 46(8), 1962-1976. doi: 10.1108/PR-07-2016-0156 
N POLOŠKI VOKIĆ, V. MOSTARAC: Obilježja i dimenzije privlačnosti poslodavaca za ekonomiste EKONOMSKI PREGLED, 72 (3) 341-357 (2021)

27. Roy, S. K. (2008). Identifying the Dimensions of Attractiveness of an Employer Brand in the Indian Context. South Asian Journal of Management, 15(4), 110130.

28. Sivertzen, A.-M., Nilsen, E. R. i Olafsen, A. H. (2013). Employer branding: employer attractiveness and the use of social media. Journal of Product \& Brand Management, 22(7), 473-483. doi: 10.1108/JPBM-09-2013-0393

29. Sommer, L. P., Heidenreich, S. i Handrich, M. (2016). War for talents-How perceived organizational innovativeness affects employer attractiveness. $R \& D$ Management, 47(2), 299-310. doi: 10.1111/radm.12230

30. Terjesen, S., Vinnicombe, S.i Freeman, C. (2007). Attracting Generation Y graduates: Organisational attributes, likelihood to apply and sex differences. Career Development International, 12(6), 504-522. doi: 10.1108/13620430710821994

31. Turban, D. B. i Greening, D. W. (1997). Corporate social performance and organizational attractiveness to prospective employees. Academy of Management Journal, 40(3), 658-672. doi: 10.2307/257057

\section{EMPLOYER ATTRACTIVENESS ATTRIBUTES AND DIMENSIONS FOR ECONOMISTS}

Summary

The paper empirically explores characteristics and dimensions that make employers attractive for the youngest generation of highly-educated economist in Croatia, due to the lack of studies on this subject. Moreover, it explores the extent to which is it relevant to segment the signals that employers send on the labour market in order to attract specific socio-demographic groups of the youngest generation of highly-educated economist. The survey conducted on the sample of 407 university graduates, by using the "Employer attractiveness scale" developed by Berthon, Ewing and Hah (2005), implies that respondents prefer the "Development dimension" of employer attractiveness As well, the inferential statistics revealed that employer attractiveness dimensions are universal, in other words that they are not significantly related to respondents' socio-demographic characteristics. Consequently, employers that want to attract and/or keep highly-educated economists of younger generations, have to provide them with opportunities for individual and career development regardless of the segment they belong to because of their individual characteristics.

Key words: employer branding, employer attractiveness, employer attractiveness attributes/ dimensions, socio-demographic characteristics of individuals, economists, Croatia, Employer attractiveness scale 